\title{
PENTINGNYA PENDIDIKAN INTERAKSI SOSIAL UNTUK KESEJAHTERAAN SOSIAL LANJUT USIA
}

\author{
MURLIS \\ STISIP Padang \\ murlis@gmail.com
}

\begin{abstract}
Entering old age, people will experience setbacks, especially physically and psychologically. However, this does not mean that changes in physical and psychological conditions make the elderly feel useless, or people who think that the elderly are useless, as argued by Argyo (2007), in many cultures and societies the elderly have a role and position. as a person who is respected, is considered to have more knowledge and experience so that it becomes a place for questions and advice for young people. Changes in systems and structures in society have implications for the role and position of the elderly in the family and society. For example, the change from a broad family form in a traditional society to a nuclear family implies that the elderly will experience life alone. Living conditions themselves are far from the attention of the family and will bring problems to the elderly, especially the elderly who do not have enough economy to meet their daily needs. Elderly people will live in poverty if there is no interaction with other people, causing various diseases in their lives.
\end{abstract}

Keywords: Education, Social Interaction, Welfare, Elderly.

Abstrak: Memasuki usia lanjut, orang akan mengalami kemunduran-kemunduran terutama secara fisik dan psikologis. Namun, tidak berarti perubahan kondisi fisik dan psikologis tersebut menjadikan lanjut usia merasa dirinya tidak berguna, atau masyarakat yang beranggapan bahwa orang lanjut usia tidak berguna, seperti yang dikemukakan oleh Argyo (2007), pada banyak kebudayaan dan masyarakat orang lanjut usia memiliki peran dan kedudukan sebagai orang yang dihormati, dianggap memiliki pengetahuan dan pengalaman yang lebih sehingga menjadi tempat bertanya dan mendapatkan nasehat bagi golongan muda.Perubahan sistem dan struktur dalam masyarakat, membawa implikasi terhadap peran dan kedudukan lanjut usia dalam keluarga dan masyarakat. Misalnya perubahan dari bentuk keluarga luas pada masyarakat tradisional ke keluarga inti (nuclear family) berimplikasi bahwa orang lanjut usia akan mengalami hidup sendiri. Kondisi hidup sendiri jauh dari perhatian keluarga akan membawa masalah terhadap orang lanjut usia, terutama orang lanjut usia yang tidak memiliki ekonomi yang cukup untuk memenuhi kebutuhan hidupnya. Orang lanjut usia hidupnya akan miskin apabila tidak ada interaksidengan orang lain,sehingga memunculkan berbagai penyakit dalam hidupnya.

Kata Kunci: Pendidikan, Interaksi Sosial, Kesejahetraan, Lanjut Usia.

\section{A. Pendahuluan}

Bentuk umum proses sosial adalah interaksi sosial, karena interaksi sosial merupakan syarat utama terjadinya aktivitas-aktivitas sosial. Bentuk lain proses sosial hanya merupakan bentuk-bentuk khusus dari interaksi sosial. Interaksi sosial merupakan hubungan-hubungan sosial yang dinamis yang menyangkut hubungan antara orang-orang perorangan, antara kelompok-kelompok manusia maupun antara orang perorangan dengan kelompok manusia. Apabila dua orang bertemu interaksi 
soisal dimulai pada saat itu. Mereka saling menegur, berjabatan tangan, saling berbicara atau bahkan mungkin berkelahi. Aktivitas-aktivitas semacam itu merupakan bentuk-bentuk interaksi sosial, menurut Gillin dan Gillin (dalam Soerjono Soekanto, 2009).

Walaupun orang-orang yang bertemu muka tersebut tidak saling berbicara atau tidak saling menukar tanda-tanda interaksi sosial telah terjadi, karena masing-masing sadar akan adanya pihak lain yang menyebabkan perubahan-perubahan dalam perasaan maupun syaraf orang-orang yang bersangkutan yang disebabkan oleh misalnya bau keringat, minyak wangi, suara berjalan dan sebagainya. Semuanya itu menimbulkan kesan di dalam pikiran seseorang, yang kemudian menentukan tindakan apa yang akan dilakukannya, Gillin dan Gillin (dalam Soerjono Soekanto, 2009).

Pengertian masalah kesejahteraan sosial pada umumnya tidak berbeda dengan masalah sosial. Masalah kesejahteraan sosial adalah masalah manusia dan lingkungan sosialnya dengan segala kompleksitas yang memiliki ciri khas yang khusus dalam menangani sasaran garapan. Melalui pembangunan bidang kesejahteraan sosial yang dilaksanakan dalam rangka pembangunan nasional selama ini tampak jelas kemajuan yang telah tercapai.

Berbagai usaha yang dilaksanakan tidak saja dapat mengatasi berbagai masalah kesejahteraan sosial setidak-tidaknya telah dapat menghambat kepesatan tumbuh dan makin berkembangnya masalah kesejahteraan sosial.

\section{B. Metdologi Penelitian}

Metode penelitian yang penulis gunakan dalam penelitian ini adalah penelitian deskriptif (descriptive research) dengan menggunakan metode penelitian kualitatif, yaitu di maksudkan untuk pengukuran yang cermat terhadap fenomena sosial tertentu. Metode penelitian kualitatif lebih berdasarkan filsafat fenomenologis yang mengutamakan penghayatan. Metode kualitatif berusaha memahami dan menafsirkan makna suatu peristiwa interaksi tingkah laku manusia dalam situasi tertentu menurut perspektif peneliti sendiri (Nazir, 1990). Metode deskriptif di maksud adalah prosedur pemecahan masalah yang diselidiki dengan menggambarkan atau melukiskan keadaan subjek atau objek penelitian (seseorang, lembaga, masyarakat) pada saat sekarang berdasarkan fakta-fakta yang tampak atau sebagaimana adanya (Nazir, 1990). Penelitian ini akan menjelaskan tentang pentingnya pendidikan interaksi sosial untuk kesejahteraan sosial lanjut usia.

\section{Hasil dan Pembahasan \\ Interaksi Sosial}

Pendidikan masalah kesejahteraan sosial lanjut usia sebagai suatu situasi yang dinilai sebagai situasi yang tidak mengenakan bagi lanjut usia. Manusia dalam perkembangannnya tidak dapat menghindarkan diri dari proses menua karena proses menua bagian dari perjalanan hidup manusia. Masalah-masalah sosial lanjut usia berkisar pada: 1) Ketergantungan : masa tua menimbulkan ketidakberdayaan. Kekuatan fisik dan mental mundur, keadaan tidak berdaya ini sedikit banyak menimbulkan ketergantungan. Sedangkan ketergantungan tersebut memerlukan suatu pertolongan dari pihak lain yang bersifat moril dan spirituil; 2) Kebutuhan :sebagai manusia lanjut usia mempunyai kebutuhan; dan 3) sebab akibat : bila ketergantungan dan kebutuhan yang mendesak dan segera tidak diatasi atau dipenuhi dapat menjadikan masalah 
Kebutuah-kebutuhan orang lanjut usia dapat dibagi menjadi 4 bagian: 1) Standart kehidupan dan tempat tinggal yang layak; 2) Hubungan sosial dan kegiatan di setiap waktu untuk mengatasi kesunyian; 3) Pemeliharaan kesehatan; dan 4) Pencegahan terhadap kerusakan yang menimpa kehidupan orang lanjut usia

Sedangkan menurut Abraham H. Maslow (dalam Sumarno Nugroho, 1987: 18), kebutuhan dasar manusia ada lima macam, yaitu: 1) Kebutuhan fisik (udara, air, makan); 2) Kebutuhan rasa aman (jasmani agar dapat bertahan dalam penghidupan serta terpusatkan kebutuhan dasarnya; 3) Kebutuhan untuk menyayangi dan disayangi; 4) Kebutuhan untuk penghargaan dari dirinya dan pihak lain; dan 5) Kebutuhan untuk mengaktualisasikan diri dari pertumbuhan.

Mengenai kebutuhan khas orang lanjut usia seperti sebagaimana telah ditegaskan dalam Petunjuk Pelaksanaan Kesejahteraan Sosial adalah sebagai berikut: 1) Terpenuhinya kebutuhan jasmani dengan baik seperti dalam bidang: Kebutuhan pokok hidup secara layak, yaitu sandang pangan, Pemeliharaan kesehatan dengan baik, Pemenuhan kebutuhan pengisian waktu luang; 2) Terpenuhinya kebutuhan rohaniah dengan baik, seperti dalam bidang: Kebutuhan kasih sayang, baik dari keluarga maupun dari masyarakat sekitar, dan Peningkatan gairah hidup dan tidak merasa khawatir dalam menghadapi sisa hidupnya; 3) Terpenuhinya kebutuhan sosial dengan baik terutama hubungan baik dengan masyarakat sekitarnya.(DEPSOS, 1984: 3)

Selain dari pendapat Abraham H. Maslow ini, ada lagi pendapat yang menyatakan kebutuhan orang lanjut usia seperti yang di kemukakan oleh Zuhairi, (2008), ia mengatakan bahwa kebutuhan manusia yang sangat mendasar yaitu kebutuhan pembinaan dan pembangunan rohani (agama) yakni untuk lebih membangkitkan perasaan dekat dengan Tuhannya, sehingga dalam batin mereka lebih tenang dan tenteram. Hal ini dilakukan adalah untuk mengatasi latar belakang orang lanjut usia yang erat kaitannya dengan asal kehidupan beragama atau keyakinan agamanya rendah. Melalui pembinaan dan pelayanan kebutuhan agama ini diharapkan dapat mengurangi masalah orang lanjut usia, sehingga mereka dapat menikmati hari tuanya dan mendapatkan ketentraman lahir dan batin. Dan juga nantinya bimbingan yang diberikan kepada orang lanjut usia adalah juga dalam rangka memperbaiki dan meningkatkan sikap, perbuatan dan tingkah laku agar selaras dan sesuai dengan ajaran agama.

Walaupun orang-orang yang bertemu muka tersebut tidak saling berbicara atau tidak saling menukar tanda-tanda interaksi sosial telah terjadi, karena masing-masing sadar akan adanya pihak lain yang menyebabkan perubahan-perubahan dalam perasaan maupun syaraf orang-orang yang bersangkutan yang disebabkan oleh misalnya bau keringat, minyak wangi, suara berjalan dan sebagainya. Semuanya itu menimbulkan kesan di dalam pikiran seseorang, yang kemudian menentukan tindakan apa yang akan dilakukannya, Gillin dan Gillin (dalam Soerjono Soekanto, 2009). Kenyataan sosial yang dialami oleh kebanyakan orang dengan cara yang paling langsung adalah interaksi tatap muka ( George Simmel dalam Johnson, 1986). Kita dapat melihat dengan mudah pentingnya dinamika-dinamika yang tidak kentara dalam proses interaksi pada tingkat tatap muka dalam kehidupan sosial. Masyarakat dapat dilihat sebagai suatu sistem bertindak dalam usaha memuaskan tujuan-tujuan sosial. Sistem bertindak seperti ini, biasanya terwujud melalui interaksi atau komunikasi timbal balik antara para anggota dalam berbagai bentuk. Interaksi melibatkan proses-proses sosial yang beraneka ragam, yang menyusun unsur-unsur dinamis dari masyarakat, yaitu proses-proses tingkah laku yang dikaitkan dengan struktur sosial. Dengan demikian 
dapat dikatakan, bahwa interaksi sosial merupakan suatu proses fundamental dalam masyarakat, tetapi interaksi sosial itu juga dipengaruhi oleh norma-norma sosial yang ada didalam kehidupan masyarakat. Interaksi sosial dapat terjadi di pasar, di ladang, di sekolah, di kantor, dalam rapat, atau dimana saja, oleh karena memang didalam interaksi sosial lokasi terjadinya itu tidak penting.

Lebih lanjut Simmel (Dalam Johnson, 1986), memberikan suatu konsepsi yang jelas mengenai interaksi sosial yang di dalamnya meliputi interaksi timbal balik. Melalui proses ini dimana individu saling berhubungan dan saling mempengaruhi satu sama lain. Interaksi sosial merupakan syarat utama bagi terjadinya aktivitas kehidupan sosial. Agar interaksi sosial dapat berjalan dengan tertib dan agar anggota masyarakat bisa berfungsi secara normal, maka diperlukan bukan hanya kemampuan untuk bertindak sesuai dengan konteks sosialnya, tetapi juga memerlukan kemampuan untuk menilai secara objektif perilaku kita sendiri dari sudut pandang orang lain. Dengan kata lain manusia dapat membayangkan dirinya sendiri secara sadar dalam perilakunya dari sudaut pandang orang lain. Sebagai akibatnya, mereka dapat mengonsentrasikan perilakunya dengan sengaja untuk membangkitkan tipe respons tertentu dari orang lain (Johnson, 1986).

\section{Bentuk dan Isi Interaksi Sosial}

Untuk memahami bentuk dan isi dari interaksi sosial selanjutnyaSimmel (dalam Johnson,1986), menjelaskan dua konsep yangdia bedakan.Khusunya, Simmel tertarik untukmengisolasikan bentuk atau pola di manaproses interaksi itu dapat dibedakan dari isi kepentingan, tujuan atau maksudtertentu yang sedangdikejar melalui Interaksi itu. Sebagai suatu analogi,matematikaadalahstudimengenai hubungan formal antara jumlah-jumlah dan proses-proses logis yang dapat diterapkan pada hubunganhubungan itu tanpa isi tertentu apapun. Geometri juga berhubungan dengan pelbagai jenis pola ruangan (spatial)serta hubungannya yang terlepas dariisi materiltertentu.Simmel menggagaskandalam suatu bayangan mengenai geometrikehidupansosial,dengan mengidentifikasi bentuk-bentuk yang dapat diabstraksikandari proses interaksi yang berlangsung terus dan dianalia secara terlepas dari isinya (Johnson, 1986).Isi kehidupan sosial meliputi: insting erotik, kepentingan obyektif, dorongan agama, tujuan membela dan menyerang, bermain, keuntungan, bantuan atau instruksi, dan tidak terbilang lainnya yang menyebabkan oranguntuk hidup bersama dengan orang lainnya, untuk bertindak terhadap mereka,bersama mereka, melawan mereka, untuk mempengaruhi orang lain dan untuk dipengaruhi oleh mereka. Tetapi pelbagai tujuan dan maksud ini tidak bersifat sosial dalam dirinya sendiri. Semuanya itu merupakan faktor-faktor dalam sosiasi hanya apabila mereka mengubah kumpulan (aggregation) individu-individu belaka yang saling terisolasi menjadi bentuk-bentuk berada bersama-sama dengan orang lain, bentuk-bentuk yang digolongkan dalam istilah umum yakni interaksi. Jadi sosiasi adalah bentuk di mana individu-individu menjadi bersama dalam satuan-satuan yang memuaskan kepentingan analisa, seperti halnya gramatika mengisolasikan bentuk-bentuk bahasa yang diterima dari isinya yang dinyatakan melalui bahasa.

Isi dan bentuk interaksi dapat bermacam-macam. Sebagai ilustrasi.Simmel mencatatbentuk-bentuk interkasi sosial (sosiasi) sebagai berikut: superioritas dan subordinasi, kompetisi, pembagian kerja, pembentukan partai, perwakilan, solidaritas ke dalam, disertai dengan sifat menutup diri terhadap orang luar, dan sebagainya. Bentuk-bentuk ini bisa dimanifestasikan dalam negara, dalam suatu komunitas agama, dalam komplotan, dalam suatu asosiasi ekonomi, dalam sekolah kesenian dan keluarga EISSN 2657-0289 Lembaga Penelitian dan Penerbitan Hasil Penelitian Ensiklopedia $\quad 39$ 
(Johnson, 1986). Pembedaan antara bentuk dan isi dapat dilihat dalam suatu situasi ruang kelas. Andaikan besarnya bersifat konstan, maka bentuk interaksi dalam suatu kelas psikologi akan mungkin sama dengan yang terdapat dalamsatukelas geologi, meskipun pokok permasalahannya berbeda. Lebih lagi, kalau kedua contoh iniberhubungan dengan isi pendidikan,ciri-ciri tertentu dari bentuk superordinasi dan subordinasi yang sama mungkin terdapat dalam suatu perusahaan dagang dalam hubungan antara pengawas dan staf. Mungkin ada beberapa perbedaan penting antara situasi-situasi ini, tetapi mereka tidak dapat di analisa menurut suatu bentuk yang lain.Salah satu contoh bentuk sosiasi atau interaksi adalah sosiabilita yaitu hubungan antara bentuk dan isi sosiasi atau interaksi yang bersifat dinamis.

Meskipun bentuk sosiasi atau interaksi merupakan alat untuk mencapai tujuan dan memenuhi pelbagai kepentingan, bentuk-bentuknya itu dapat dipisahkan dari isinya, dan karenanya bentuk-bentuk itu dapat dilihat demi bentuk-bentuk itu sendiri. Dan kalau sosiasi atau interkasi itu dipisahkan dari isinya sendiri atau isi yang tidak ada hubungannya dengan itu, maka bentuk yang dihasilkan adalah sosiabilita. Dalam beberapa hal semua interaksi bersifat sosiabel, atau sekurang-kurangnya bersifat sosial. Tetapi sosiabilita sebagai suatu bentuk yang murni, merupakan interaksi itu sendiri dan bukan untuk tujuan yang lain. Contoh sosiabilita ada banyak, yang paling jelas adalah interaksi dalam suatu silaturahmi. Harapan dari diadakannya silaturahmi adalah bahwa orang yang akan berinteraksi, tetapi interaksi mereka tidak terbatas pada masalah praktis sehari-hari. Dalam beberapa hal, percakapan mengenai hal-hal yang terjadi setiap hari sebenarnya dianggap kurang menarik. Misalnya orang bisa bekerja sama dengan baik dalam kantor bertahun-tahun lamanya dan mempunyai kepentingan yang sama, tatapi pada saat silaturahmi lain (Natal misalnya) orang mengerti bahwa mereka tidak akan membicarakan masalah bisnis (Johnson, 1986).

Pemisahan isi material atau yang praktis dari bentuk sosiabilitayang murni dapat juga diamati dalam interaksi antara orang-orang asing. Mereka tidak memiliki isi kehidupan sehari-hari yang sama, hubungan mereka satu-satunya adalah kehadiran mereka bersama yang sementara sifatnya. Mereka mungkin saling bersikap acuh tak acuh, tetapi kalau mereka memulai berinteraksi, maka interaksinya itu akan mungkin mencerminkan bentuk sosiabilita yang murni. Jadi mungkin mereka bersenda-gurau mengenai cuaca, meskipun mereka tidak saling membutuhkan informasi, dan mereka mengetahui hal itu. Pokok pembicaraan tidak sepenting kenyataan yang menjadi dasar bagi bentuk sosiabilita (Johnson, 1986).

\section{Faktor-faktor Terjadinya Interaksi Sosial}

Menurut Soerjono Soekanto (2009), berlangsungnya suatu proses interaksi didasarkan pada pelbagai faktor, antara lain, faktor imitasi, sugesti, identifikasi dan simpati. Faktor-faktor tersebut dapat bergerak sendiri-sendiri secara terpisah maupun dalam keadaan tergabung. Apabila masing-masing ditinjau secara lebih mendalam, faktor imitasi misalnya, mempunyai peranan yang sangat penting dalam proses interaksi sosial. Salah satu segi positifnya adalah bahwa imitasi dapat mendorong seseorang untuk mematuhi kaedah-kaedah dan nilai-nilai yang berlaku. Namun demikian imitasi mungkin pula mengakibatkan terjadinya hal-hal yang negatif dimana misalnya, yang ditiru adalah tindakan-tindakan yang menyimpang. Selain itu, imitasi juga dapat melemahkan atau bahkan mematikan pengembangan daya kreasi seseorang.

Faktor sugesti berlangsung apabila seseorang memberi suatu pandangan atau sesuatu sikap yang berasal dari dirinya yang kemudian diterima oleh pihak lain. Jadi 
proses ini sebenarnya hampir sama dengan imitasi, tetapi tolak ukurnya berbeda. Berlangsungnya sugesti dapat terjadi karena pihak yang menerima dilanda oleh emosi yang menghambat daya secara rasional.Mungkin proses sugesti terjadi apabila yang memberikan pandangan adalah orang yang berwibawa atau mungkin karena sifatnya yang otoriter. Kiranya mungkin pula bahwa sugesti terjadi oleh sebab yang memberikan pandangan atau sikap merupakan bagian terbesar dari kelompok yang bersangkutan, atau masyarakat.

Identifikasi sebenarnya merupakan kecenderungan-kecenderungan atau keinginan-keinginan dalam diri seseorang untuk menjadi sama dengan pihak lain. Identifikasi sifatnya lebih mendalam dari pada imitasi, karena kepribadian seseorang dapat terbentuk atas dasar proses ini. Proses identifikasi dapat berlangsung dengan dirinya (secara tidak sadar) maupun dengan disengaja karena seringkali seseorang memerlukan tipe-tipe ideal tertentu di dalam proses kehidupannya. Walaupun dapat berlangsung dengan sendirinya proses identifikasi berlangsungnya dalam suatu keadaan dimana seseorang yang beridentifikasi benar-benar mengenal pihak lain (yang menjadi idealnya) sehingga pandangan, sikap maupun kaedah-kaedah yang berlaku pada pihak lain tadi dapat melembaga dan bahkan menjiwainya. Nyatalah bahwa berlangsungnya identifikasi mengakibatkan terjadinya pengaruh yang lebih mendalam ketimbang proses imitasi dan sugesti walaupun ada kemungkinan bahwa pada mulanya proses identifikasi diawali oleh imitasi dan atau sugesti.

Proses simpati sebenarnya merupakan suatu pproses dimana seseorang merasa tertarik pada pihak lain. Di dalam proses ini perasaan memegang peranan yang sangat penting walaupun dorongan utama pada simpati adalah keinginan untuk memahami pihal lain dan untuk bekerja sama dengannya. Inilah perbedaan utamanya dengan identifikasi yang didorong oleh keinginan untuk belajar dari pihak lain yang dianggap kedudukannya lebih tinggi dan harus dihormati karena mempunyai kelebihankelebihan atau kemampuan-kemampuan tertentu yang patut dijadikan contoh. Proses simpati akan dapat berkembang di dalam suatu keadaan dimana faaktor saling mengerti terjamin. Hal-hal tersebut di atas merupakan faktor-faktor minimal yang menjadi dasar bagi berlangsungnya proses interkasi sosial, walaupun didalam kenyataan proses tadi memang sangat kompleks, sehingga kadang-kadang sulit mengadakan perbedaan tegas antara faktor-faktor tersebut. Akan tetapi, dapatlah dikatakan bahwa imitasi dan sugesti terjadi lebih cepat, walau pengaruhnya kurang mendalam bila dibandingkan dengan identifikasi dan simpati yang secara relatif agak lebih lambat proses berlangsungnya.

\section{Syarat-syarat Terjadinya Interaksi Sosial}

Interaksi sosial merupakan hubungan sosial yang dinamis, menyangkut hubungan antara individu, antara kelompok maupun antara individu dengan kelompok, yang terjadi tersebut sebagai kesatuan dan biasanya menyangkut tujuan yang hendak dicapai dalam kehidupan sosial. Walaupun di dalam kenyataanya proses tadi memang sangat kompleks, sehingga kadang-kadang sulit untuk mengadakan pembedaan tegas antara faktor-faktor minimal yang menjadi dasar bagi berlangsungnya proses interaksi sosial.

Suatu interaksi sosial tidak akan mungkin terjadi apabila tidak memenuhi dua syarat, seperti yang dikatakan oleh Soerjono Soekanto (2009), yaitu:

1. Adanya kontak sosial (social-contact), yang dapat berlangsung dalam tiga bentuk, yaitu antara individu, antara individu dengan kelompok, dan antar kelompok. Selain itu, suatu kontak sosial dapat pula bersifat langsung ataupun tidak langsung. 
2. Adanya komunikasi, yaitu seseorang memberi arti pada perilaku orang lain, perasaan-perasaan apa yang ingin disampaikan oleh orang tersebut. Orang yang bersangkutan kemudian memberi reaksi terhadap perasaan yang ingin disampaikan oleh orang tersebut.

Pentingnya kontak sosial dan komunikasi bagi terwujudnya interaksi sosial dapat diuji terhadap suatu kehidupan sosial yang terasing. Kehidupan terasing yang sempurna ditandai dengan ketidakmampuan untuk mengadakan interaksi sosial dengan pihak-pihak lain. Sudah tentu seseorang yang hidup terasing sama sekali dapat melakukan tindakan-tindakan, misalnya terhadap alam sekitarnya, tetapi hal itu tak akan mendapatkan tanggapan apa-apa.Oleh sebab itu interaksi sosial merupakan kunci semua kehidupan sosial, karena tanpa adanya interaksi sosial, tak akan mungkin ada kehidupan bersama.

\section{Penutup}

Untuk mengurangi kecemasan, memberikan rasa aman dan ketenangan diri orang lanjut usia, kelompok maupun keluarga tempat tinggal orang lanjut usia penting sebagai pihak yang memberikan cukup kenyamanan serta keamanan bagi orang lanjut usia. Pendekatan lain meliputi interaksi, pengembangan kesukaan/ hobi juga biasa dilakukan untuk memaksimalkan potensi yang ada orang lanjut usia sekaligus memberikan keselarasan dengan sisitem sosial yang ada. Seperti yang di kemukakan oleh Edi Indrizal (2005), hubungan sosial orang lanjut usia dengan keluarga dan warga masyarakat penting bagi orang lanjut usia untuk mengurangi rasa kecemasan, memberikan rasa aman dan ketenangan. Selanjutnya dia mengatakan struktur keluarga, ikatan solidaritas sosial, dan tradisi merantau kesemuanya fungsional sebagai jaminan sosial bagi orang lanjut usia sehingga orang lanjut usia tidak boleh hidup tersia-sia di hari tuanya, maka hal itu dapat menjadi aib bagi keluarga, kerabat atau bahkan orang sekitar. Namun dalam kondisi yang berubah dalam masyarakat Minangkabau kotemporer, diantaranya perubahan struktur keluarga luas ke keluarga inti, pola menetap neolokal, membawa konsekuensi perubahan fungsi struktur keluarga dan hubungan sosial dalam masyarakat Minangkabau. Perubahan-perubahan fungsi struktur keluarga membawa implikasi terhadap kehidupan orang lanjut usia. Orang lanjut usia tanpa anak memperoleh masalah tersendiri di dalam masyarakat dan tampaknya masalah sosial lebih dominan dibandingkan masalah menurunnya kondisi fisik akibat usia yang bertambah tua, sehingga dalam kenyataannya interaksi sosial itu langsung mempengaruhi kesejahteraan lanjut usia.

\section{Daftar Pustaka}

Agus, Bustanuddin, 2005,Agama Dalam Kehidupan Manusia, Jakarta, Raja Grafindo Persada.

Afrizal, 2001, "Hubungan Keluarga, Manajemen Kekayaan, Perubahan Sosial dan Kesejahteraan Sosial Lanjut Usia di Minangkabau Matrilinial Kontemporer" dalam Franz von Benda-Beckmann dkk. (peny.) Sumber Daya Alam dan Jaminan Sosial. Yogyakarta: Pustaka Pelajar.

-------, 2008, Pengantar Metode Penelitian Kualitatif, Labor Sosiologi FISIP Universitas Andalas Padang.

Blake. L, 1992 Growing Old In The Malay Community. Centre For Advanced Studies BPS, 2011,Sumatera Barat Dalam Angka, tahun data 2010, BPS Propinsi Sumatera Barat 
Beckmann, Franz Von Benda, 2001, Sumber Daya Alam, dan Jaminan Sosial, Yogyakarta, Pustaka Pelajar IKAPI

Demartoto, Argyo, 2007, Pelayanan Sosial Bagi Lanjut usia, Surakarta, UNS Press

Departemen Sosial RI. 1986. Undang-undang RI No 6 Tahun 1974, Tentang Ketentuan Pokok Kesejahteraan Sosial. Direktorat Jendral Bantuan Sosial, Jakarta

Departemen Sosial RI. 1998. Undang-undang RI No 13 Tahun 1998, Tentang Kesejahteraan Lanjut Usia. Jakarta

Johnson D. P,1986, Teori Sosiologi Klasik dan Modern, Jakarta, PT Gramedia

John R., An Introduction to concept and issues. San Diego: San Diego State University. Terjemahan Arifin, Elfa, (2001). Pertumbuhan Penduduk Dunia. Makalah. Tidak dipublikasikan

JIPTUMM, 2004, Perspektif Sosial Ekomomi Orang Lanjut usia Terhadap Kesejahteraan. Universitas Muhammadiyah Malang.

Huky Will, D. A, 1986, Pengantar Sosiologi, Surabaya, Usaha Nasional

Indrizal, Edi. 2005. Problem Orang Lanjut usia Tanpa Anak di Dalam Masyarakat Minangkabau, Sumatera Barat. Jurnal Antropologi Indonesia. Vol. 29, No 1 Januari 2005. Hal 69-92

Miles, M. B dan Huberman, 1992, Qualitatif data Analysis, Terjemahan Rohidi, Jakarta, Universitas Indonesia Press.

Moh. Sholeh. Imam Musbikin, 2005, Agama Sebagai Terapi Telaah, Yogyakarta, Pustaka Pelajar.

Moleong, Lexy J. 2000, Metodologi Penelitian Kualitatif, Bandung, Remaja Rosda Karya.

Navis, A.A 1984. Alam Terkembang Jadi Guru: Adat dan Kebudayaan Minangkabau. Jakarta : Grafiti Pers.

Nazir, M, 1990, Metode Penelitian Sosial, Jakarta, Gramedia

Soetarso, 1997, Kesejahteraan Sosial, Pelayanan Sosial, Bandung STKS.

Soekanto, Soerjono, 2009, Sosiologi Suatu Pengantar, Jakarta, Rajawali Pers.

Suyanto Bagong, 2010. Sosiologi Teks Pengantar dan Terapan, Jakarta, Rencana Pranada Media Group.

Undang-undang RI No 6 Tahun 1974, Tentang Ketentuan Pokok Kesejahteraan Sosial. Jakarta

Soemarno Nugroho T. 1987. Sistem Intervensi Kesejahteraan Sosial, Hanindita. Jakarta.

Soerjono Soekanto. 1990. Sosialogi Keluarga (tentang ikhwal keluarga, remaja dan anak-anak), Rineka Cipta, Jakarta.

Soetarso, 1997, Kesejahteraan Sosial, Pelayanan Sosial dan Kebijaksanaan Sosial, Bandung : STKS

Wahyudi Nugroho. 1995. Perawatan Lanjut Usia, penerbit buku kedokteran, EGC, Jakarta.

Yun Marga Lita, 2001, Pendidikan Agama Islam Terhadap Orang Lanjut Usia di desa Balai Batu Sandaran Kecamatan Berangin Sawahlunto, IAIN Imam Bonjol Padang 